Jurnal Kesehatan Karya Husada, Vol 8 No 2 Tahun 2020

PISSN 2337649X/EISSN 2655-8874

Siti Fatimah, Agustina Retno Hapsari, Mayasari Styaningsih, Nur Fatimah "Gambaran Tekanan Darah, Kadar Glukosa dan Asam Urat pada Masyarakat Dusun Panggungan, Trihanggo, Gamping, Sleman” (hal 84-95)

Received

06 Juni 2020

Revisied

28 Juli 2020

Acceptep

15 Oktober 2020

\title{
GAMBARAN TEKANAN DARAH, KADAR GLUKOSA DAN ASAM URAT PADA MASYARAKAT DUSUN PANGGUNGAN, TRIHANGGO, GAMPING, SLEMAN
}

\author{
Siti Fatimah ${ }^{1)}$, Agustina Retno Hapsari ${ }^{2)}$, Mayasari Styaningsih ${ }^{3)}$, Nur Fatimah ${ }^{4)}$ \\ ${ }^{1}$ Program Studi Promosi Kesehatan, Politeknik Kesehatan Karya Husada Yogyakarta \\ Email: \\ sitifatimah023.sf@gmail.com \\ ${ }^{2}$ Program Studi DIII Keperawatan, Politeknik Kesehatan Karya Husada Yogyakarta \\ ${ }^{3}$ Mahasiswa Program Studi DIII Keperawatan, Politeknik Kesehatan Karya Husada Yogyakarta \\ ${ }^{4}$ Mahasiswa Program Studi DIII Keperawatan, Politeknik Kesehatan Karya Husada Yogyakarta
}

\begin{abstract}
ABSTRAK
Penyakit tidak menular (PTM) dapat dikendalikan melalui deteksi dini faktor risiko, diantaranya melalui pemeriksaan tekanan darah dan gula darah. Penelitian ini bertujuan untuk memperoleh gambaran faktor risiko PTM di masyarakat Panggungan. Metode yang dilakukan yaitu penelitian deskriptif dengan pendekatan kuantitatif berdasarkan pemeriksaan tekanan darah, gula darah, dan asam urat pada 103 subjek. Hasil penelitian ini menunjukkan bahwa sebanyak $37 \%$ warga memiliki tekanan darah yang tinggi, 27\% warga memiliki kadar gula darah tinggi dan $28 \%$ memiliki kadar asam urat yang tinggi. Berdasarkan penelitian ini dapat disimpulkan bahwa terdapat warga Panggungan yang memilki faktor risiko PTM. Data yang diperoleh diharapkan dapat bermanfaat untuk rencana program kesehatan prefentif ke depan, terutama di Dusun Panggungan.
\end{abstract}

Kata Kunci: PTM; tekanan darah; kadar gula darah; kadar asam urat

\begin{abstract}
Non-communicable diseases (NCDs) can be managed through early detection of risk factors, including checking blood pressure and blood sugar. This study aims to obtain an overview of the risk factors for NCDs in the Panggungan community. This research was descriptive research with a quantitative approach based on examination of blood pressure, blood sugar, and uric acid in 103 subjects. Results of this study indicated that as many as 37\% of residents had high blood pressure, $27 \%$ had high blood sugar levels and $28 \%$ had high uric acid levels. Based on this research, it can be concluded that there are Panggungan residents who have risk factors for NCDs. The data obtained is expected to be useful for future preventive health program plans, especially in Panggungan community.
\end{abstract}

Keywords: NCDs; blood pressure; blood sugar levels; uric acid level 
Jurnal Kesehatan Karya Husada, Vol 8 No 2 Tahun 2020

PISSN 2337649X/EISSN 2655-8874

Siti Fatimah, Agustina Retno Hapsari, Mayasari Styaningsih, Nur Fatimah "Gambaran Tekanan Darah, Kadar Glukosa dan Asam Urat pada Masyarakat Dusun Panggungan, Trihanggo, Gamping, Sleman” (hal 84-95)

\section{PENDAHULUAN}

Penyakit tidak menular (PTM) adalah penyebab utama pada $71 \%$ kematian di dunia (WHO, 2018). Penyakit ini juga disebut dengan noncommunicable disease, yang penanganannya lebih sulit dibandingkan dengan penyakit menular. Hal ini disebabkan karena PTM lebih sulit didiagnosa, membutuhkan waktu yang panjang sampai menimbulkan gejala dan etiologi yang sering tidak jelas (Darmawan, 2016).

Pada tahun 2016, PTM telah menyebabkan kematian pada 57 juta penduduk dunia. Persentase terbanyak disebabkan oleh penyakit kardiovaskuler sebanyak $44 \%$, disusul oleh kanker $22 \%$, penyakit pernafasan kronis 9\%, dan diabetes 4\%. Penyakit ini juga mengakibatkan kematian menjadi prematur, yaitu kematian yang terjadi di bawah usia 60 tahun. Dari semua kejadian kematian prematur, sebanyak 75\% diantaranya disebabkan oleh PTM. Selain itu, penyakit ini banyak diderita di negara dengan low and middle income country, dengan persentase $78 \%$ kematian. Negara ini termasuk di dalamnya adalah Indonesia (WHO 2018).

Di Indonesia, terjadi peningkatan kasus PTM berdasarkan perbandingan data Riskesdas tahun 2018 dan 2013. Prevalensi kanker naik dari 1,4 persen (Kemenkes, 2013) menjadi 1,8 persen di 2018. Begitu pula dengan prevalensi stroke naik dari 7 persen menjadi 10,9 persen, sementara penyakit ginjal kronik naik dari 2 persen menjadi

3,8 persen. Berdasarkan pemeriksaan gula darah, prevalensi diabetes melitus naik dari 6,9 persen menjadi 8,5 persen dan hasil pengukuran tekanan darah, hipertensi naik dari 25,8 persen menjadi 34,1 persen (Riskesdas, 2018).

Upaya promotif dan preventif merupakan salah satu kebijakan yang direkomendasikan dalam manajemen PTM di Indonesia. Strategi yang dapat dilakukan di masyarakat untuk deteksi dini PTM yaitu melalui posbindu PTM yang terdiri dari lima meja. Pemeriksaan yang dilakukan dalam posbindu PTM meliputi pemeriksanaan tekanan darah dan gula darah (Kemenkes RI, 2019). Melalui pemeriksaan tersebut akan dapat dideteksi penyakit 
Jurnal Kesehatan Karya Husada, No 8 Vol 2 Tahun 2020

PISSN 2337649X/EISSN 2655-8874

Siti Fatimah, Agustina Retno Hapsari, Mayasari Styaningsih, Nur Fatimah "Gambaran Tekanan Darah, Kadar Glukosa dan Asam Urat pada Masyarakat Dusun Panggungan, Trihanggo, Gamping, Sleman” (hal 84-95)

metabolik yang merupakan indikator dalam deteksi dini PTM (Dasopang dkk., 2015).

Program posbindu idealnya dimiliki oleh setiap posyandu. Namun kenyataan di lapangan tidak semua desa memiliki posbindu. Di Daerah Istimewa Yogyakarta (DIY), ketercapaian pembentukan posbindu masih belum memenuhi target. Pada tahun 2016, posbindu yang terbentuk sebanyak 226 dari 440 yang ditargetkan, sehingga belum semua masyarakat dapat mendeteksi dini PTM (Dinkes DIY,2017). Penelitian ini dilakukan di Dusun Panggungan yang merupakan salah satu wilayah di Kabupaten Sleman. Pemeriksaan yang dilakukan yaitu tekanan darah, kadar gula darah dan asam urat. Data dari penelitian ini diharapkan mampu menjadi dasar dalam melaksanankan program kesehatan ke depan, khususnya di Dusun Panggungan.

\section{METODE}

Metode yang digunakan dalam penelitian ini yaitu penelitian deskriptif dengan pendekatan kuantitatif berdasarkan hasil pemeriksaan tekanan darah, gula darah dan asam urat (Sugiyono, 2012). Subjek dalam penelitian ini yaitu sebanyak 103 warga Panggungan yang datang memeriksakan diri pada posko pemeriksaan kesehatan. Kriteria usia pada penelitian ini seperti halnya kriteria posbindu, yaitu usia di atas 15 tahun (Kemenkes RI, 2019).

Pengumpulan data dilakukan dalam kegiatan jalan sehat dalam rangka memperingati Hari Sumpah Pemuda pada tanggal 27 Oktober 2019 pukul 08.00-12.00 WIB. Meskipun pemeriksaan yang dilakukan terdapat 3 jenis, namun tidak semua warga bersedia diperiksa keseluruhan dengan alasan telah terbiasa menjalani pemeriksaan tersebut, terutama pemeriksaan tekanan darah.

Warga dengan kriteria inklusi secara suka rela datang untuk memeriksakan diri. Tim peneliti merupakan dosen dan mahasiswa Poltekkes Karya Husada Yogyakarta yang memiliki latar belakang pendidikan perawat dan promotor kesehatan. Tim dibagi menjadi bagian pendaftaran, pemeriksaan 
Jurnal Kesehatan Karya Husada, No 8 Vol 2 Tahun 2020

PISSN 2337649X/EISSN 2655-8874

Siti Fatimah, Agustina Retno Hapsari, Mayasari Styaningsih, Nur Fatimah "Gambaran Tekanan Darah, Kadar Glukosa dan Asam Urat pada Masyarakat Dusun Panggungan, Trihanggo, Gamping, Sleman” (hal 84-95)

tekanan darah, pemeriksaan gula darah dan asam urat, serta pendataan hasil pemeriksaan. Pengukuran tekanan darah yang dilakukan menggunakan spignomanometer jarum dan digital yang telah dikalibrasi. Sedangkan pengukuran asam urat dan gula darah sewaktu dilakukan dengan Easy Touch $®$ GCU, sesuai dengan petunjuk pemakaian alat. Warga yang datang akan didata nama, serta RT dan diberikan kartu pemeriksaan yang akan diisi petugas.

Kartu ini nantinya akan dibawa pulang subjek agar mengetahui keseluruhan hasil pemeriksaan yang dilakukan. Kemudian dilakukan pemeriksaan tekanan darah, gula darah dan asam urat pada subjek. Tekanan darah dikategorikan menjadi 4, yaitu yaitu normal $(<120 /<80 \mathrm{mmHg})$, meningkat $\quad(120-129 /<80 \mathrm{mmHg})$, hipertensi tingkat 1 (130-139/80-89 $\mathrm{mmHg}$, dan hipertensi tingkat 2 ( $\geq 140 / \geq 90 \quad \mathrm{mmHg}$ ) (Whelton dkk.,2018). Gula darah dikatakan tinggi apabila gula darah sewaktu $\geq 200$ mg/dL (Soelistijo, 2015). Sedangkan asam urat dikatakan tinggi apabila $\geq 6$ mg/dL (Juraschek, 2015).

Perekapan data hasil pemeriksaan dilakukan di pos terakhir. Pada saat pemeriksaan, peneliti akan langsung memberikan feedback. Apabila hasilpemeriksaan normal maka tim memberikan tips untuk mempertahankan kesehatan, apabila hasil tidak normal akan diberikan edukasi dan direkomendasikan untuk melakukan pemeriksaan lebih lanjut ke puskesmas.

\section{HASIL DAN PEMBAHASAN}

Penelitian ini dilakukan pada 103 subjek yang terdiri dari 26 laki-laki (25\%) dan 77 perempuan (75\%) yang terdapat dalam tabel dan gambar di bawah ini.

Tabel 1. Proporsi Peserta Berdasarkan Jenis

\begin{tabular}{clc}
\hline No & Jenis Kelamin & Jumlah \\
\hline 1 & Laki-laki & 26 \\
\hline 2 & Perempuan & 77 \\
\hline
\end{tabular}

Pemeriksaan kesehatan yang telah dilakukan terdiri dari pemeriksaan tekanan darah, pemeriksaan gula darah dan asam urat, dengan hasil sebagai

berikut. 
Jurnal Kesehatan Karya Husada, No 8 Vol 2 Tahun 2020

PISSN 2337649X/EISSN 2655-8874

Siti Fatimah, Agustina Retno Hapsari, Mayasari Styaningsih, Nur Fatimah "Gambaran Tekanan Darah, Kadar Glukosa dan Asam Urat pada Masyarakat Dusun Panggungan, Trihanggo, Gamping, Sleman” (hal 84-95)

\section{Tekanan Darah}

Pemeriksaan tekanan darah diikuti oleh 87 peserta yang terdiri dari 21 peserta laki-laki dan 66 peserta perempuan. Dari peserta laki-laki, 24\% memiliki tekanan darah normal, $28 \%$ memiliki tekanan darah rendah dan $48 \%$ memiliki tekanan darah tinggi. Sedangkan proporsi tekanan darah untuk peserta perempuan terdiri $41 \%$ memiliki tekanan darah normal, $26 \%$ memiliki tekanan darah rendah dan $33 \%$ memiliki tekanan darah tinggi.

Tabel 2. Proporsi Peserta Berdasarkan Jenis

\begin{tabular}{ccccc}
\hline No & $\begin{array}{c}\text { Jenis } \\
\text { Kelamin }\end{array}$ & Tinggi & Normal & Rendah \\
\hline 1 & Laki-laki & 10 & 5 & 6 \\
\hline 2 & Perempuan & 22 & 27 & 17 \\
\hline & Jumlah & 32 & 32 & 23 \\
\hline
\end{tabular}

\section{Gula Darah}

Pemeriksaan gula darah diikuti oleh 96 peserta, dengan jumlah peserta lakilaki sebanyak 21 orang dan peserta perempuan sebanyak 75 orang. Dari

21 peserta laki-laki, sebanyak $73 \%$ memiliki kadar gula normal dan $27 \%$ memiliki kadar gula tinggi. Sedangkan untuk peserta perempuan, dari 75 peserta terdapat $73 \%$ yang memiliki kadar gula normal dan $27 \%$ memiliki kadar gula tinggi.

Tabel 3. Kadar Gula darah berdasarkan Jenis Kelamin

\begin{tabular}{clcc}
\hline No & $\begin{array}{c}\text { Jenis } \\
\text { Kelamin }\end{array}$ & Normal & Tinggi \\
\hline 1 & Laki-laki & 15 & 6 \\
\hline 2 & Perempuan & 55 & 20 \\
\hline
\end{tabular}

\section{Asam Urat}

Pemeriksaan asam urat diikuti oleh 99 peserta yang terdiri 25 peserta laki-laki dan 74 peserta perempuan. Pada peserta laki-laki terdapat $76 \%$ yang memiliki kadar asam urat normal dan $24 \%$ yang memiliki kadar asam urat tinggi. Pada Tinggi Normal Rendah peserta perempuan, 69\% diantaranya memiliki kadar asam urat normal dan $31 \%$ diantaranya memiliki kadar asam urat tinggi.

Tabel 4. Proporsi Kadar Asam Urat

Berdasarkan

\begin{tabular}{clcc}
\hline No & Jenis Kelamin & Normal & Tinggi \\
\hline 1 & Laki-laki & 19 & 6 \\
\hline 2 & Perempuan & 51 & 23 \\
\hline
\end{tabular}

\section{PEMBAHASAN}

Salah satu masalah yang dihadapi dalam pembangunan kesehatan saat ini yaitu 
Jurnal Kesehatan Karya Husada, No 8 Vol 2 Tahun 2020

PISSN 2337649X/EISSN 2655-8874

Siti Fatimah, Agustina Retno Hapsari, Mayasari Styaningsih, Nur Fatimah "Gambaran Tekanan Darah, Kadar Glukosa dan Asam Urat pada Masyarakat Dusun Panggungan, Trihanggo, Gamping, Sleman” (hal 84-95)

pergeseran tren penyakit dari penyakit infeksi menjadi PTM. Penyakit tidak menular telah menjadi penyebab utama kematian, tidak hanya di Indonesia, namun juga di dunia. Menurut WHO, pada tahun 2016 sebanyak 71\% kematian di dunia disebabkan oleh PTM (WHO, 2018). Di Indonesia, 6 dari 10 penyebab kematian, enam diantaranya adalah PTM yang terdiri dari stroke, hipertensi, diabetes, tumor ganas, penyakit hati dan jantung iskemik (Kemenkes RI, 2013).

Menurut analisis Sample Registration Survey (SRS) tahun 2014 dan Badan Litbangkes menunjukan hasil dengan pola yang serupa. Secara nasional, 10 penyebab kematian yang tertinggi adalah penyakit pembuluh darah otak (21\%), penyakit jantung iskemik (12,9\%), diabetes melitus (6,7\%). TBC (5,7\%), hipertensi dengan komplikasinya $(5,3 \%)$, penyakit saluran nafas bawah kronik $(4,9 \%)$, penyakit hati $(2,7 \%)$, kecelakaan transportasi $(2,6 \%)$, pneumonia $(2,1 \%)$ dan diare (1,9\%) (Kritina dkk., 2019).
Dengan demikian, penyebab kematian tertinggi didominasi oleh stroke, penyakit jatung dan pembuluh darah; diabetes mellitus; dan hipertensi dengan komplikasinya. Penyakit metabolik yang merupakan kunci penyakit tidak menular yaitu kelebihan berat badan/obesitas, tekanan darah meningkat/hipertensi, glukosa darah yang tinggi dan kadar kolesterol yang meningkat.

Berdasarkan hasil pemeriksaan, 37\% peserta mengalami hipertensi. Pada peserta laki-laki $48 \%$ diantaranya mengalami hipertensi sedangkan pada perempuan $33 \%$ diantaranya mengalami hipertensi. Menurut WHO (2013) hipertensi bertanggung jawab setidaknya $45 \%$ dari kematian akibat penyakit jantung (total mortalitas penyakit jantung iskemik dan 51\% kematian akibat stroke).

Hipertensi merupakan penyakit tidak menular, penyakit degeneratif ini banyak terjadi dan mempunyai tingkat mortalitas yang cukup tinggi serta mempengaruhi kualitas hidup dan 
Jurnal Kesehatan Karya Husada, No 8 Vol 2 Tahun 2020

PISSN 2337649X/EISSN 2655-8874

Siti Fatimah, Agustina Retno Hapsari, Mayasari Styaningsih, Nur Fatimah "Gambaran Tekanan Darah, Kadar Glukosa dan Asam Urat pada Masyarakat Dusun Panggungan, Trihanggo, Gamping, Sleman” (hal 84-95)

produktifitas seseorang. Lebih dari $30 \%$ sampel mengalami tekanan darah tinggi.

Tekanan darah tinggi ini berkaitan dengan faktor usia, jenis kelamin, gaya hidup, genetik dan disebabkan penyakit sekunder lainnya. Pada umumnya laki- laki lebih berisiko terserang hipertensi dibandingkan dengan perempuan.

Hal ini disebabkan karena laki-laki banyak mempunyai faktor yang mendorong terjadinya hipertensi seperti lelah, stres dalam pekerjaan, kebiasaan merokok dan pola makan tidak teratur (Anggara dan Prayitno, 2013). Tekanan darah tinggi sendiri dapat menimbulkan berbagai masalah kesehatan seperti penyakit jantung, maupun stroke. Upaya pencegahan hipertensi yang dapat dilakukan diantaranya perubahan gaya hidup. Hipertensi merupakan penyakit yang timbul akibat adanya interaksi dari berbagai faktor risiko yang dimiliki seseorang. Faktor risiko penyakit tidak menular yang dapat dikendalikan yaitu gaya hidup, diantaranya usia, merokok, pola makan tidak sehat, kurang aktifitas fisik, obesitas, stress, hipertensi, hiperglikemi dan hiperkolesterol (Tamnge dan Munir, 2018).

Pada pemeriksaan gula darah, sebanyak 27\% pada peserta laki-laki maupun perempuan mengalami kadar gula darah yang tinggi. Berdasarkan penelitian yang dilakukan sebelumnya, kadar gula darah pada perempuan biasanya lebih tinggi daripada laki-laki karena perempuan memiliki kecenderungan lebih suka mengkonsumsi makanan manis tanpa diimbangi dengan olahraga yang teratur (Bistara dkk., 2019).

Diabetes adalah penyakit kronis yang terjadi ketika pankreas tidak dapat memproduksi insulin yang cukup, atau ketika tubuh tidak dapat secara efektif menggunakan insulin yang dihasilkan tubuh. Hal ini menyebabkan peningkatan konsentrasi glukosa dalam darah (Fatimah, 2015). Diabetes merupakan penyakit dengan jumlah kasus yang tinggi secara global dan nasional. Menurut World Health Organization (WHO, 2016), pada tahun 
Jurnal Kesehatan Karya Husada, No 8 Vol 2 Tahun 2020

PISSN 2337649X/EISSN 2655-8874

Siti Fatimah, Agustina Retno Hapsari, Mayasari Styaningsih, Nur Fatimah "Gambaran Tekanan Darah, Kadar Glukosa dan Asam Urat pada Masyarakat Dusun Panggungan, Trihanggo, Gamping, Sleman” (hal 84-95)

2014 angka global diabetes adalah 422 juta jiwa $(8,5 \%$ dari total penduduk dunia). Angka mortalitas global yang diakibatkan oleh diabetes pada tahun 2012 adalah 1,5 juta jiwa dengan angka prevalensi tertinggi terdapat pada negara middle dan low income.

WHO menambahkan bahwa diabetes akan menjadi penyakit ke 7 penyumbang angka kematian tertinggi pada tahun 2030. International Diabetes Federation (IDF) menambahkan, pada tahun 2015 terdapat 10 juta jiwa pengidap diabetes di Indonesia atau dengan angka prevalensi sebesar $6,2 \%$ total penduduk Indonesia. Kemenkes RI melalui data Riskesdas 2013 menyatakan bahwa DIY merupakan Provinsi yang memiliki angka diabetes tertinggi nasional dengan angka prevalensi sebesar 2,6\% (Kemenkes RI, 2013).

Berdasarkan hasil riset kesehatan dasar (Riskesdas) Kemenkes RI pada tahun 2018, pravelensi diabetes melitus berdasarkan hasil diagnosis dokter pada penduduk berusia lebih dari 15 tahun mencapai $4,79 \%$. Presentase tersebut meningkat dari hasil riset 5 tahun sebelumnya yaitu sebanyak 3,4 persen pada tahun 2013. Jika dibandingkan dengan rata-rata nasional, maka prevalensi penderita diabetes melitus di kota Yogyakarta mencapai lebih dari dua kali lipat dibanding prevalensi nasional yang hanya dua persen (Kemenkes RI, 2018).

Prevalensi diabetes di DIY meningkat $1,6 \%$ setiap bulannya, dengan rata-rata jumlah pasien di RSUD Jogja sebanyak 73 pasien dengan komplikasi setiap bulannya. Diabetes merupakan penyakit yang tidak dapat diabaikan karena berbagai komplikasi dapat terjadi apabila tidak dikendalikan. Komplikasi diabetes yang kronis dapat menyebabkan nefropati, kebutaan, neuropati dan bahkan amputasi organ yang telah membusuk (Perkeni, 2015).

Sedangkan prevalensi subjek yang memiliki kadar asam urat tinggi yaitu28\%, dengan penderita asam urat pada peserta perempuan lebih tinggi daripada laki-laki, yaitu $31 \%$. Asam urat yang menumpuk dalam sendi dapat mengakibatkan deformitas atau 
Jurnal Kesehatan Karya Husada, No 8 Vol 2 Tahun 2020

PISSN 2337649X/EISSN 2655-8874

Siti Fatimah, Agustina Retno Hapsari, Mayasari Styaningsih, Nur Fatimah "Gambaran Tekanan Darah, Kadar Glukosa dan Asam Urat pada Masyarakat Dusun Panggungan, Trihanggo, Gamping, Sleman” (hal 84-95)

perubahan bentuk yang disebabkan pengeroposan tulang. Sehingga efek jangka panjangnya tulang menjadi mudah patah.

Asam urat dikatakan tinggi ketika kadarnya melebihi $7 \mathrm{mg} / \mathrm{dL}$ pada lakilaki dan $6 \mathrm{mg} / \mathrm{dL}$ pada perempuan. Kadar asam urat yang tinggi dapat menyebabkan berbagai komplikasi, seperti terbentuknya gout artritis dan batu ginjal. Kadar asam urat tinggi yang terjadi secara tidak terkendali dapat menyebabkan peningkatan risiko kematian akibat penyakit pembuluh darah (kardiovaskular), seperti gagal jantung kongestif dan stroke (Prihatmawati dan Badi'ah, 2013).

Upaya yang dapat dilakukan untuk mengendalikan kadar asam urat yaitu dengan cara mengurangi makanan yang mengandung banyak purin. Beberapa gaya hidup yang dianjurkan antara lain menurunkan berat badan, mengkonsumsi makanan sehat, olahraga, menghindari rokok, dan mengonsumsi air yang cukup.
Pada penderita artritis gout dengan riwayat batu saluran kemih disarankan untuk mengkonsumsi dua liter air tiap harinya dan menghindari kondisi kekurangan cairan. Untuk latihan fisik penderita artritis gout sebaiknya berupa latihan fisik yang ringan, agar tidak mengalami trauma pada sendi (Jordan dkk., 2007).

\section{SIMPULAN DAN SARAN}

Dari hasil pemeriksaan kesehatan di Dusun Panggungan dapat disimpulkan bahwa terdapat anggota masyarakat memiliki faktor risiko PTM, terutama penyakit hipertensi. Berdasarkan pemeriksaan, terdapat $37 \%$ warga yang menderita hipertensi, $27 \%$ warga yang menderita diabetes dan $28 \%$ yang menderita asam urat. Data ini dapat dijadikan sebagai landasan dalam melakukan program kesehatan di masyarakat, khususnya di Dusun

Panggungan. 
Jurnal Kesehatan Karya Husada, No 8 Vol 2 Tahun 2020

PISSN 2337649X/EISSN 2655-8874

Siti Fatimah, Agustina Retno Hapsari, Mayasari Styaningsih, Nur Fatimah "Gambaran Tekanan Darah, Kadar Glukosa dan Asam Urat pada Masyarakat Dusun Panggungan, Trihanggo, Gamping, Sleman” (hal 84-95)

\section{DAFTAR PUSTAKA}

Alwan, A. (2011). Global status report on noncommunicable diseases 2010. World Health Organization.

Anggara, F. H. D., \& Prayitno, N. (2013).Faktor-faktor yang berhubungan dengan tekanan darah di Puskesmas Telaga Murni, Cikarang Barat tahun2012. Jurnal IlmiahKesehatan, 5(1), 20-25.

Bistara, D. N., Zahroh, C., \& Wardani, E.M. (2019). Tingkat Stres Dengan Peningkatan Kadar Gula Darah Penderita Diabetes Mellitus. Jurnal Ilmiah Keperawatan (Scientific Journal of Nursing), 5(1), 77-82.

Damayanti, S. (2015). Hubungan Antara Frekuensi Senam Diabetes Mellitus Dengan Kadar Gula

Darah, Kadar Kolesterol dan Tekanan Darah pada Klien Diabetes Mellitus Tipe 2 di Kelompok Persadia RS Jogja. Medika Respati, 10(2).
Darmawan, A., \& Epid, M. (2016). Epidemiologi penyakit menular dan penyakit tidak menular. $J M J, 4(2)$.

Dinas Kesehatan Provinsi DIY (2017). Profil Kesehatan DIY. Yogyakarta: Dinas Kesehatan Provinsi DIY.

Fatimah, R. N. (2015). Diabetes melitus tipe 2. Jurnal Majority, 4(5).

Jordan, K. M., Cameron, J. S., Snaith, M., Zhang, W., Doherty, M., Seckl, J.,... \& Nuki, G. (2007). British Society for Rheumatology and British Health Professionals in Rheumatology guideline for the management of gout. Rheumatology, 46(8), 1372-1374.

Kemenkes, R. I. (2013). Riset kesehatan dasar

(Riskes

das) 2013. Jakarta: Badan Penelitian dan Pengembangan Kesehatan. 
Jurnal Kesehatan Karya Husada, No 8 Vol 2 Tahun 2020

PISSN 2337649X/EISSN 2655-8874

Siti Fatimah, Agustina Retno Hapsari, Mayasari Styaningsih, Nur Fatimah "Gambaran Tekanan Darah, Kadar Glukosa dan Asam Urat pada Masyarakat Dusun Panggungan, Trihanggo, Gamping, Sleman” (hal 84-95)

Kemenkes, R. I. (2018). Hasil utama RISKESDAS 2018.

Online) http://www. depkes. go. id/resources/download/infoterkini/materi_rakorpop_2018/Hasi $1 \%$ 20Riskesdas, 202018.

Kemenkes, R. I. (2019). Buku Pedoman Manajemen Penyakit Tidak Menular. Jakarta: Direktorat Pencegahan dan Pengendalian Penyakit Tidak Menular.

Kemenkes, R. I. (2019). Petunjuk Teknis

Pos

Pembinaa

n Terpadu bagi Kader. Jakarta:

Direktorat Pencegahan dan

Pengendalian Penyakit Tidak

Menular.

Kristina, K., Pangaribuan, L., \& Hendrik, $\mathrm{H}$. (2019).

Gambaran Penyebab Kematian

Utama di Kabupaten Bekasi

Provinsi Jawa Barat 2011.

Buletin

Penelitian

Kesehatan, 47(1), 29-38.
Lusiana, N., Widayanti, L. P., Mustika, I., \& Andiarna, F. (2019). Korelasi Usia dengan Indeks Massa Tubuh, Tekanan darah SistolDiastol, Kadar Glukosa, Kolesterol, dan Asam Urat. Journal of Health Science and Prevention, 3(2), 101-108.

Perkeni, P. B. (2015). Konsensus pengelolaan dan pencegahan diabetes melitus tipe 2 di Indonesia. Jakarta: PB Perkeni.

Prihatmawati, W., \& Badi'ah, A. (2013).

Pengaruh

Pendidikan Kesehatan Melalui

Small Group Discussion terhadap

Pengetahuan dan Sikap Ibu Usia

30-50 Tahun tentang Asam

Urat di Dusun Jatisari

Sawahan Ponjong Gunungkidul

(Doctoral dissertation,

STIKES'Ais yiyah Yogyakarta).

Soelistijo, S. A., Novida, H., Rudijanto, A., Soewondo, P., Suastika, K., Manaf, A., \& Zufry, H. (2015).

Konsensus pengelolaan dan pencegahan diabetes melitus tipe 
Jurnal Kesehatan Karya Husada, No 8 Vol 2 Tahun 2020

PISSN 2337649X/EISSN 2655-8874

Siti Fatimah, Agustina Retno Hapsari, Mayasari Styaningsih, Nur Fatimah "Gambaran Tekanan Darah, Kadar Glukosa dan Asam Urat pada Masyarakat Dusun Panggungan, Trihanggo, Gamping, Sleman” (hal 84-95)

2 di Indonesia 2015. Jakarta:

PB Perkeni, 1-93.

Sugiyono. (2012). Metode

Penelitian Kuantitatif, Kualitatif dan $R \& D$. Bandung: Alfabeta.

Tamnge, W. A. S., \& Munir, M. (2018).Pelayanan Tenaga

Kesehatan dengan Pemeriksaan Kesehatan Rutin dalam Program Germas di Sukolilo Tuban. STIKES Nahdlatul Ulama Tuban..

Whelton, P. K., Carey, R. M., \& Aronow, W. S. (2018). Acc/aha/aapa/abc/acpm/ags/APhA/ ASH/ASPC/nma/pcna guideline for the prevention,

Detection, evaluation, and management of high blood pressure in adults: a Report of the American College of Cardiology/American heart Association. Task force on clinical practice guidelines//J. Am. Coll. Cardiol.-2017.-Nov 13. Почки, $7(1)$.

WHO, G. (2013). WHO methods and data sources for global burden of disease estimates 2000-2011. Geneva: Department of Health Statistics and Information Systems.

WHO . (2016). Global Report On Diabetes. WHO Library Cataloguing - in - Publication Data. France.

World Health Organization. (2018). Noncommunicable diseases country profiles 2018. 